\title{
Analysis of Ratio Return on Equity, Quick Ratio, Debt to Equity Ratio, Towards Internet Financial Reporting and Size of Companies As Moderating Variables (Empirical Study on Sub Sectors of Various Industries Listed in Indonesia Stock Exchange)
}

\author{
Diah Iskandar
}

Accounting Study Program, Faculty Economics and Business, Universitas Mercu Buana

DOI: $\underline{10.36348 / \text { sjef.2020.v04i05.005 }}$

| Received: 16.04.2020 | Accepted: 27.04.2020 | Published: 30.05.2020

*Corresponding author: Diah Iskandar

Abstract

The accountants are demanded to have competent competence in making financial statements that are technically and technologically qualified. So in the era of industrial revolution 4.0, the accountant profession is also required to understand big data that stores a lot of information, not only financial data but also non-financial aspects. According to Abdillah (2016) states that Internet Financial Reporting is one of the voluntary disclosures because no regulations are governing what content should be presented by the company's website. Most publicly listed companies have a personal website that provides essential company information. In conclusion, an accountant profession must understand the internet financial reporting system or disclosure of corporate financial reporting through the company's website is one of the methods that must be studied by the accounting profession. This study aims to examine the effect of Return on Equity, Quick Ratio, and Debt to Equity Ratio on Internet Financial Reporting and Company Size as a Moderating Variable. The results of this study indicate that Return on Equity, Quick Ratio to Internet Financial Reporting cannot be moderated by Company Size, whereas Debt to Equity Ratio to Internet Financial Reporting can be reduced by Company Size.

Keywords: Return on Equity, Quick Ratio, Debt to Equity Ratio, Company Size, Internet Financial Report.

Copyright @ 2020: This is an open-access article distributed under the terms of the Creative Commons Attribution license which permits unrestricted use, distribution, and reproduction in any medium for non-commercial use (NonCommercial, or CC-BY-NC) provided the original author and source are credited.

\section{INTRODUCTION}

Internet media has become a tool that provides a means for disclosure of corporate financial reporting as information to external parties because openness can reduce the level of information asymmetry that can occur in financial statements, so as to accelerate company growth. The nature and characteristics of the internet that is easily spread (pervasiveness), knows no boundaries (borderlessness), on time (real time), low cost (low cost), makes disclosure of information through the company's website easier to find all necessary information related to the company, without having to pay a high cost, Abdillah [1]. The development of the internet creates a new way of delivering company financial statement information that is using the Internet Financial Repoting (IFR) system, Yuli Kurniawati [2].

With the phenomenon of an increasing number of internet users signifying that a company can make it an opportunity to publish its financial statements. From the investor side, providing easy access to information contained in the company. While from the company side, it can reduce costs in terms of publishing financial statements or printing and sending them to the investor. Increasing the number of internet users, most companies that have gone public are using the internet to deliver company information in the form of financial information or in the form of company profiles and other information through the company's official website or personal website.

Based on BEI's publication on Monday (1/8/2018), a total of 637 companies were listed on the exchange. In details, 555 listed companies are required to submit interim financial reports as of 30 September 2017, while 82 securities and other listed companies are not required to provide financial reports. According to IDX records, as of 2 January 2018, there are 11 companies that have not submitted financial reports. A total of 7 of them have not submitted Interim Financial 
Statements as of 30 September 2017 which have not been reviewed in a limited manner or that have not been audited by a Public Accountant until 30 December 2017.

And 7 companies that have not submitted their financial statements that have not been audited by a public accountant as of 30 September 2017 will be subject to a written warning letter III. And 3 companies that have not submitted their audited financial statements by a public accountant with a deadline of 30 September 2017 to 2 January 2017, will be subject to a written warning I. Guided by the provisions of IDX II.6.1 Regulation 1-H: Regarding Sanctions, Exchanges has given a written warning I to 11 listed companies that do not meet the obligation to submit audited financial statements that end on December 31, 2017 in a timely manner. From the announcement issued, there are names of companies in various industrial sectors, PT Nipress Tbk included in the group of companies that have not submitted financial statements audited by public accountants in a timely manner. With the condition of PT Nipress Tbk which has an official website owned by the company for financial reporting with the website address www.nipress.com as a means to facilitate the company in disclosing financial statements in a timely manner (source: marketbisnis.com)

Internet Financial Reporting (IFR) can be seen as an effective communication medium for external users of information such as investors; companies that implement IFR practices are currently used by large companies that have sophisticated technology, one of which is applied by manufacturing sector companies, Febrian Rizki [3]. According to Abdillah [4] states that Internet Financial Reporting is one of the voluntary disclosures because there are no regulations governing what content should be presented by the company's website. Most publicly listed companies have private websites that provide important company information. With the existence of internet media can facilitate the use of information contained in the company to external parties to find out the company's business conditions, company finances and company performance, Kurniawati [2].

The liquidity ratio is an indicator of the level of a company's ability to pay for short-term obligations. If the company's situation is not liquid, there is a tendency for the company to go bankrupt, Agustina Khikmawati [5]. Ratios are projected using Current Ratio is about the comparison between current assets and current debt. In Agustina Khikmawati's research [5] shows the liquidity ratio has an influence on Internet Financial Reporting but a significant negative effect on Internet Financial Reporting (IFR).

The leverage ratio is a ratio that becomes an indicator of a company's capital structure. A high degree of leverage can encourage management to conduct Internet Financial Reporting to take advantage of opportunities for useful information from the company. According to Agustina Khikmawati's research [5] states that leverage ratios have no significant effect on Internet Financial Reporting. Whereas in the study of Riyan Andriyani [6], it says that partially it has a positive impact on Internet Financial Reporting.

The size of the company is a big or small picture of a company that can be measured from the value of assets, total sales, or from the market value of the company's equity. According to Kurniawati [2], said that large companies are more highlighted in the capital market, which puts pressure on companies to disclose information about the company. According to Kuniawati's research [2], the results of the relationship of Company Size have a significant positive effect, while Dina's research [7] states that in his study, company size variables have no significant impact.

Based on previous research, it was found that there were differences regarding inconsistent results about the effect of profitability, liquidity, leverage, on Internet financial reporting, and company size as a moderating variable in manufacturing companies in various industry sub-sectors. So the authors are interested in conducting further research with the title "Analysis of Profitability Ratios, Liquidity Ratios, Leverage Ratios, Internet Financial Reporting and Company Size as Moderating Variables (Empirical Study of Manufacturing Companies in Various Industries Sub Sector Sectors Listed in Indonesia Stock Exchange Period 2016 - 2018) ".

\section{Formulation of the Problem}

Based on a background explanation of the factors affecting internet financial reporting in an increase in manufacturing companies in various industry sub-sectors. The wording of the research problem is as follows:

1. Does Return On Equity affect internet financial reporting?

2. Does Quick Ratio affect internet financial reporting?

3. Does Debt To Equity Ratio affect internet financial reporting?

4. Does the size of the company moderate the relationship between profitability ratios, liquidity, leverage affect the internet financial reporting?

\section{LITERATURE REVIEW, THOUGHTS OF THOUGHTS AND HYPOTHESES Internet Financial Reporting}

Internet Financial Reporting is a process by companies that their financial reporting via the internet through a website owned by the company [8]. Disclosure of company information, both financial and non-financial on the company's website is known as the 
Internet financial reporting [9]. Internet financial reporting appears and develops as the fastest media tool to inform matters related to the company [10].

It can be concluded that there is a tendency for management to determine how to maximize the objectives of the company in practice Internet Financial Reporting as a medium for companies to convey all information on their accountability to external parties as the agency contract has been desired [11].

According to research, Malawat [12] states that Internet Financial Reporting can show views if the company reports its financial statements through the company's website can indicate that the company has good news. Still, vice versa, if the company experiences delays or even does not publish on the company's official website, it will show bad news to the company.

\section{Profitability}

Profitability ratios are ratios to assess a company's ability to seek profits. This ratio also provides a measure of the effectiveness of a company's management. This can be demonstrated by the profits generated from the sales and investment income of the company. It can be concluded that the use of this ratio can show the efficiency of the company [9].

According to Arfianda [10], profitability is an indicator of performance by management in managing company wealth, as indicated by the profits generated. In practice, there are several types of methods of calculating profitability ratios, namely profit margin ratio, return on assets (ROA) and return on equity (ROE) [13]. In this study, the method used to measure profitability ratios using ROE, because ROE is a measure of the effectiveness of management in managing the company-owned investment.

With this, it can be concluded that if the rate of return on investment shows the productivity of all company funds, both loan capital, and own capital. The smaller the ratio produced the less good or the inability of management to obtain ROE [13].

\section{Liquidity}

According to Ade Kemala Jaya and Verawati [14] states that the Liquidity Ratio to show the company's ability to meet financial obligations that must be met, or the company's ability to meet business requirements when billed. Economic analysis can use multiple liquidity ratios to assess the ability to pay obligations that must be paid immediately.

Liquidity ratios are ratios that illustrate a company's ability to meet short-term obligations. And the function of the liquidity ratio is to measure the company's ability to meet its requirements that are due, in the form of commitments for external parties or private company [13].

In this study, the Liquidity Ratio uses a quick ratio (Quick Ratio). According to Hanafi [15], this ratio uses assets that will turn into cash faster, and because inventory is considered the longest-running current asset to turn into money, assets that are included in addition to money are securities and receivables.

\section{Leverage}

According to Kurniawati [2] states that the Leverage Ratio as a measure of the number of assets financed using liabilities. And this Leverage ratio shows the company's ability to pay obligations if the company is liquidated. With the results, if the company with a high proportion of leverage can show a greater risk of the company because of the possibility that the company cannot pay off its obligations.

In practice to cover the lack of funding needs, the company has several choices of funding sources that can be used. In this case, the leverage ratio is the ratio used to measure the extent to which the company's assets can be financed with debt. This means how the company bears much debt burden compared to assets owned by the company [13].

In this study, the Leverage Ratio used is Debt to Equity Ratio is the ratio used to assess all debt with all equity. To find out every capital of the company that is used for debt collateral. Because for creditors, the greater the ratio will be unprofitable because the higher the risk of failure that may be borne by the company [13].

\section{Company Size}

The size of the company has a different effect on the value of the company of a company. In terms of company size seen from the total assets owned by the company, which can be used for company activities. In this case, the size of the company is assessed by the log of total assets. Registration of Total Assets is used to reduce the significant difference between the size of the company that is too large with the size of the company that is too small. The total asset value is formed into a natural logarithm.

\section{Framework}

In this study, using five variables, namely Profitability Ratios, Liquidity Ratios, and Leverage Ratios, as independent variables, and Internet Financial Reporting as dependent variables (Dependent Variables). The framework of thought is made to make it easier to understand the effect of Profitability Ratios, Liquidity Ratios, Leverage Ratios to Internet Financial Reporting (IFR), and Company Size as moderating variables. Then the framework of thought is presented as follows: 


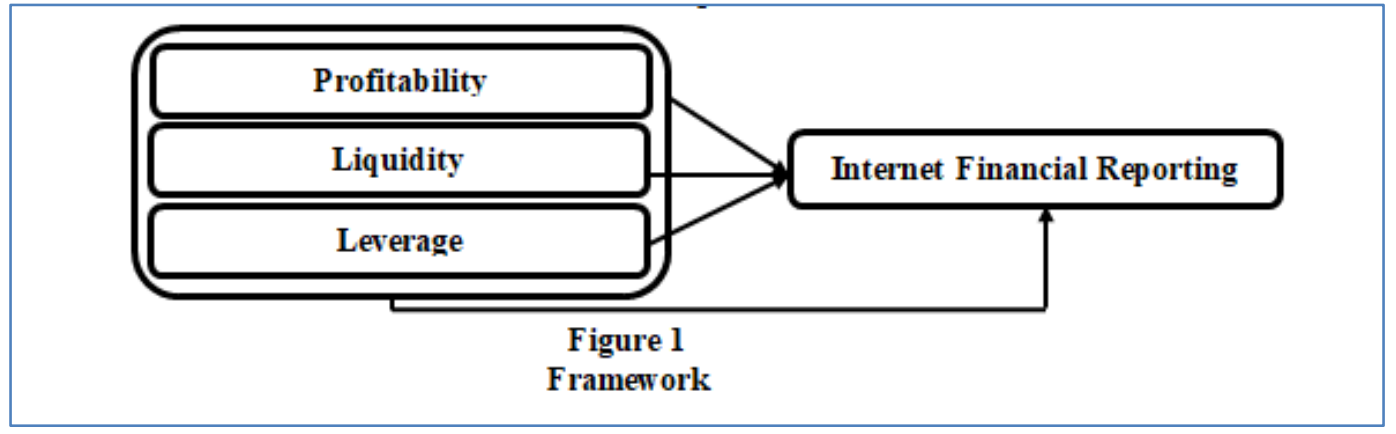

\section{HYPOTHESIS}

1. Profitability Ratios and Internet Financial Reporting (IFR)

Profitability Ratio is a ratio used to measure a company's ability to generate profits by utilizing company-owned assets [5].

The profit that can be generated by the company is an achievement expected by the management and investors of the company. So if the company that has a high level of profitability tends to make more disclosures about the company's profitability information [5].

Efforts to publish top profitability information to the public because company management wants to show the public and stakeholders and can be compared with other similar companies [5]. Based on the description, the hypothesis can be formulated as follows:

H1: positive Return On Equity effect on Internet Financial Reporting

\section{Liquidity Ratios and Internet Financial Reporting (IFR)}

Liquidity is a ratio that can help answer the question of problems companies can pay debts within a predetermined maturity or a ratio that can provide a picture of the company's ability to pay debts that are due in one year [11]. Then it can be concluded that the company can still pay short-term liabilities, either the condition of the company that is stable or even in a liquid state.

The level of liquidity owned by the company will affect investors in making decisions in investing. Because less liquid companies will provide assumptions to investors that the company will go bankrupt. Then this hypothesis is formulated as follows:

H2: Quick Ratio has a positive effect on Internet Financial Reporting (IFR)

\section{Leverage Ratio and Internet Financial Reporting (IFR)}

In managing the company to obtain high profits, sometimes companies use debt to support company activities or which is often referred to as leverage [8].

Companies with a high degree of leverage have a high risk as well because there is a possibility that the company cannot calculate its obligations. This situation will threaten the management position in the company. Companies with a high degree of leverage will try to avoid disclosure of their reporting through the internet media to prevent the wrong assumptions that will be accepted by the company [8]. Then from these assumptions, the following hypothesis is formulated:

H3: Debt To Equity Ratio has a positive effect on Internet Financial Reporting (IFR).

\section{Company Size and Internet Financial Reporting (IFR)}

The value of company size is measured by market capitalization increasing by one point. Generally, large companies have several shareholders and creditors that are large and widespread, resulting in them having to report the financial statements as a whole to their parties. To reduce agency costs such as the costs of publishing financial statements as electronic goods and printing as well as shipping the charges of financial statements, these companies use internet financial reporting. Large companies are also faced with administrative expenses as a form of corporate social responsibility to the public and government. To reduce costs, the company is using internet financial reporting to decrease regulatory pressure from the government and environmentally-conscious organizations. Based on these assumptions, the hypothesis can be formulated as follows:

H4: Firm size moderates the relationship between profitability, liquidity, and leverage ratios affect the internet financial reporting

\section{RESEARCH METHODS \\ Population and Research Samples}

The population is the area of generalization, objects/subjects that have certain qualities and characteristics determined by researchers to be studied and then drawn conclusions [16]. The population in this study is manufacturing companies of various industrial 
sub-sectors listed on the Indonesia Stock Exchange from 2016 to 2018 , amounting to 23 companies.

The sample is part of the number and characteristics possessed by the population [16]. Sampling in this study uses a purposive sampling technique where purposive sampling is a sampling technique or data source with specific considerations. The aim is to obtain a research sample that matches the criteria specified.
The sample criteria that will be used are

1. Manufacturing Companies of various industrial sub-sectors listed on the Indonesia Stock Exchange in 2016 - 2018.

2. Manufacturing Companies of various industrial sub-sectors that did not experience a loss in the 2018 study

Table-1: Details of Research Samples

\begin{tabular}{|c|l|c|}
\hline No & \multicolumn{1}{|c|}{ Details } & Total \\
\hline 1 & $\begin{array}{l}\text { Manufacturing companies of various industrial sub-sectors listed on the } \\
\text { Indonesia Stock Exchange in 2016 - 2018 }\end{array}$ & 46 \\
\hline 2 & $\begin{array}{l}\text { Manufacturing Companies Sub-sectors of multiple industries that suffered } \\
\text { losses in the study period 2016 - 2018 }\end{array}$ & $(18)$ \\
\hline 3 & $\begin{array}{l}\text { Manufacturing companies of various industrial sub-sectors that are } \\
\text { delisting and new IPO }\end{array}$ & $(5)$ \\
\hline & Number of Samples & 23 \\
\cline { 2 - 3 } & Observation Year & 69 \\
\cline { 2 - 3 } & The total amount of data during the Research Period & 3 \\
\hline
\end{tabular}

Source: www.idx.co.id (2019) processed data

\section{Data Analysis Method}

The analytical method used in this study uses the Statistical Package for Social Sciences (SPSS) 20 for windows. The data analysis methods that can be used in this study are as follows:

\section{Descriptive Statistics}

Descriptive statistics are used to describe the data in this study consisting of profitability (ROE), liquidity, leverage, activity ratios, company size, and Internet Financial Reporting (IFR). Measurements used in this study are the minimum value, maximum value, mean, and standard deviations [17].

\section{Hypothesis Test}

a. Significance of Individual Parameters (Test Statistics t)

T statistical test shows how far the influence of one explanatory/independent variable individually in explaining the variation of the dependent variable (Ghozali, 2016: 97). b. Multiple Linear Regression Analysis In this study, multiple regression analysis is used to examine the effect of the independent variables, specifically on the dependent variable (Ghozali, 2016). This study uses five independent variables, one dependent variable, and as stated in the regression equation below:

$$
\begin{aligned}
& \mathrm{IFR}=\alpha+\beta_{1} \mathrm{ROA}+\beta_{2} \mathrm{CR}+\beta_{3} \mathrm{DER}+\beta_{4} \mathrm{SIZE}+\mathrm{e} \\
& \text { Details: } \\
& \text { IFR : Internet financial Reporting } \\
& \alpha \quad \text { : Constanta. } \\
& \beta \quad \text { : Regression Coefficient } \\
& \text { ROA : Return on Assets } \\
& \text { CR : Current Ratio } \\
& \text { DER : Debt Equity Ratio } \\
& \text { Size : Company size } \\
& \text { e : Error }
\end{aligned}
$$

\section{RESEARCH RESULTS AND DISCUSSION Descriptive statistics}

Table-2

\begin{tabular}{|r|c|c|c|c|c|}
\hline \multicolumn{7}{|c|}{ Descriptive Statistics } \\
\hline & $\mathrm{N}$ & $\begin{array}{c}\text { Minimu } \\
\mathrm{m}\end{array}$ & $\begin{array}{c}\text { Maximu } \\
\mathrm{m}\end{array}$ & Mean & $\begin{array}{c}\text { Std. } \\
\text { Deviation }\end{array}$ \\
\hline IFR & 69 &, 38240 &, 88240 &, 6460145 &, 11566496 \\
\hline Profitability & 69 &, 00035 &, 31783 &, 1051061 &, 08305869 \\
\hline Liquidity & 69 &, 64860 & 5,49290 & 2,2434246 & 1,28692400 \\
\hline Leverage & 69 &, 03050 & 2,52230 &, 5360333 &, 51746461 \\
\hline Size & 69 & 25,21560 & 33,47370 & 28,3487348 & 1,65932729 \\
\hline Valid N (listwise) & & & & & \\
\hline
\end{tabular}


From the results of descriptive statistical tests, information is obtained that the Internet Financial Reporting variable has a range of values from 0.38 to 0.88 , which is the lowest value. The average amount of Internet Financial Reporting is 0.6460, and the standard deviation is 0.11566 .

The profitability variable with roa proxy has a range of values from 0,00035 to 0.31783 , which is the lowest value. The average amount of Company Value is 0.1051 and standard-deviation of 0.08305 .

The liquidity variable with proxy cr has a range of values from 0.64860 to 5.4929 , which is the lowest value. The average amount of Liquidity is 2.2434, and the standard deviation is 1.28692 .

The variable Leverage with proxy der has a range of values from 0.0305 to 2.52230 , which is the lowest value. The average cost is 0.53603 , and the standard deviation is 0.51746 .

Company Size Variable with proxy size has a range of values from 25.21560 to 33.47370 , which is the lowest value. The average cost is 28.34573 , and the standard deviation is 1.65932 .

\section{HYPOTHESIS TESTING Model 1 Regression Equation}

Table-3: Regression Coefficient Model 1

\begin{tabular}{|c|c|c|c|c|c|c|}
\hline \multicolumn{7}{|c|}{ Coefficients $^{\mathrm{a}}$} \\
\hline & \multirow[t]{2}{*}{ Model } & \multicolumn{2}{|c|}{ Unstandardized Coefficients } & \multirow{2}{*}{$\begin{array}{c}\text { Standardized Coefficients } \\
\text { Beta }\end{array}$} & \multirow[t]{2}{*}{$\mathrm{T}$} & \multirow[t]{2}{*}{ Sig. } \\
\hline & & $\mathrm{B}$ & Std. Error & & & \\
\hline \multirow[t]{4}{*}{1} & (Constant) &, 652 &, 040 & & 16,394 & ,000 \\
\hline & Profitability & 089 &, 175 & ,064 &, 508 & 613 \\
\hline & Liquidity &,- 011 & ,012 &,- 122 &,- 923 & ,359 \\
\hline & Leverage &, 018 & 030 & 081 & ,599 & 551 \\
\hline \multicolumn{7}{|c|}{ a. Dependent Variable: IFR } \\
\hline
\end{tabular}

This model is used to test the effect of Profitability, Liquidity, and Leverage on Internet Financial Reporting. The regression model is systematically formulated as follows:

$$
\text { IFR }=0,652+0,089 \text { ROA-0,011 CR+0.018 DER+e }
$$

Where:

a. $\quad \beta 0=0.652$; meaning that if Profitability, Liquidity, and Leverage is 0 , then Internet Financial Reporting is worth 0.652

b. $\quad \beta 1=0.089$; meaning that if profitability increases by 1 , then Internet Financial Reporting also increases by 0.089 .

\section{Model 2 Regression Equation}

Table-4: Regression Coefficient Model 2

\begin{tabular}{|c|c|c|c|c|c|c|}
\hline \multicolumn{7}{|c|}{ Coefficients $^{\mathrm{a}}$} \\
\hline & \multirow[t]{2}{*}{ Model } & \multicolumn{2}{|c|}{ Unstandardized Coefficients } & \multirow{2}{*}{$\begin{array}{c}\text { Standardized Coefficients } \\
\text { Beta } \\
\end{array}$} & \multirow[t]{2}{*}{$\mathrm{T}$} & \multirow[t]{2}{*}{ Sig. } \\
\hline & & $\mathrm{B}$ & Std. Error & & & \\
\hline \multirow[t]{2}{*}{1} & (Constant) &,- 796 & ,165 & & $-4,818$ &, 000 \\
\hline & Size & ,051 & ,006 & ,730 & 8,741 &, 000 \\
\hline \multicolumn{7}{|c|}{ a. Dependent Variable: IFR } \\
\hline
\end{tabular}

This model is used to test the effect of Size of the Company that is proxyed by Size on Internet Financial Reporting. The regression model is systematically formulated as follows: c. $\quad \beta 2=-0,011$; meaning that if Liquidity increases by 1, then Internet Financial Reporting will decrease by 0.011 .

d. $\quad \beta 3=0.018$; meaning that if leverage increases by 1 , then Internet Financial Reporting also increases by 0.011 .

The $\mathrm{t}$ test in model 1 shows the calculated $\mathrm{t}$ value of Profitability (0.508), Liquidity (-0.923), and Leverage (0.599) smaller than the table value for model 1 of 2.75. In addition, the resulting significance value of Profitability (0.613), Liquidity (0.359), and Leverage (0.551) greater than 0.05 . Then it can be concluded that partially Profitability, Liquidity, and Leverage has no effect on Internet Financial Reporting. a. Dependent Variable: IFR

Where:

$$
\text { IFR }=-0,796+0,051 \mathrm{SIZE}+\mathrm{e}
$$

a. $\quad \beta 0=-0,796$; this means that if the Company Size variable is 0 , then Internet Financial Reporting is 0,796 
b. $\quad \beta 4=0.051$; meaning that if the Company Size variable increases by 1 person and the other variables are constant, then Internet Financial Reporting rises by 0.051 .

\section{Model 3 Regression Equation}

Table-5: Regression Coefficient Model 3

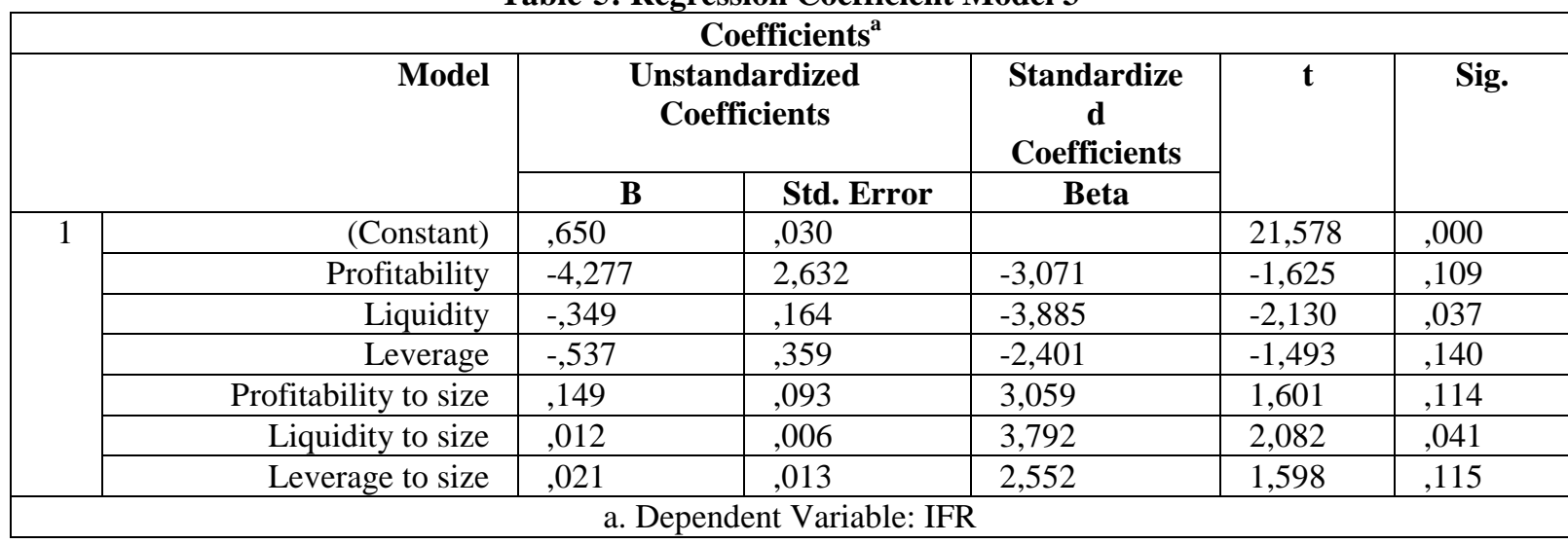

This model is used to test the effect of Profitability, Liquidity, and Leverage on Internet Financial Reporting by being moderated by Company Size proxied by SIZE. The regression model is systematically formulated as follows:

$$
\begin{aligned}
\mathrm{IFR}= & 0,650-4,277 \mathrm{ROA}-0,349 \mathrm{CR}-0,537 \mathrm{DER}+ \\
& 0,149 \text { Profitability } * \text { Uk.Company }+0.012 \\
& \text { Liquidity * Uk.Company }+0.021 \text { Leverage } * \\
& \text { Uk.Company }+\mathrm{e}
\end{aligned}
$$

Where:

a. $\quad \beta 5=0.149$, meaning that if the Company Size variable increases by 1 percent, it will strengthen the profitability trend by 0.149 .

b. $\quad \beta 6=0.012$, saying that if the Company Size variable increases by 1 percent, it will enhance the tendency of liquidity by 0.012 units.

c. $\quad \beta 7=0.021$, meaning that if the Company Size variable increases by 1 percent, it will strengthen the Leverage tendency by 0.021 .

The T-test in model 3, profitability moderated by company size, shows the resulting significance value of 0.114 , which is higher than 0.05 . Then it can be concluded that partially the effect of profitability on Internet Financial Reporting can be strengthened insignificantly by Company Size as a moderating variable.

The T-test, in model 3, Liquidity moderated by Company Size, shows the resulting significance value of 0.041 , which is smaller than 0.05 . Then it can be concluded that partially the Effect of Liquidity on Internet Financial Reporting can be significantly strengthened by Company Size as a moderating variable.
The $t$ test on model 2 of Company Size shows model 2 of 2.75 . In addition, the resulting significance value of 0,000 is greater than 0.05 . Then it can be concluded that partially the size of the company affects the Internet Financial Reporting. the $t$ value of 8.741 is greater than the table value for

The T-test in model 3, Leverage, which is moderated by Company Size, shows the resulting significance value of 0.115 , which is more significant than 0.05 . Then it can be concluded that partially the influence of leverage on Internet Financial Reporting can be strengthened insignificantly by Company Size as a moderating variable.

\section{DISCUSSION}

1. In model 1 shows that partially Profitability, Liquidity, and Leverage do not affect Internet Financial Reporting. This means that if the company is unable to find a profit, fulfill obligations in the long and short term, this does not have an impact on measuring through a reporting index that measures IFR timeliness that can be seen from the completeness of reporting on the company's website.

2. The size of the company produces an assessment that partially significant influence on Internet Financial Reporting. This is because all of the samples used have total assets, net sales, and large market capitalization so that the company has a higher obligation to disclose financial statements more fully as a form of management's accountability to shareholders.

3. T-Test Results to see the effect of Profitability, Liquidity, and Leverage on Internet Financial Reports, which are moderated by Company Size, produce different assessments. Partially, company size can strengthen the relationship between profitability, liabilities, leverage, and internet financial reporting. And the profitability and liquidity of the Internet Financial Reporting cannot be moderated by the size of the company. At the 
same time, the force of internet financial reporting can be reduced by the size of the company.

\section{CONCLUSIONS AND SUGGESTIONS \\ Conclusion}

From the results of this study, the following conclusions can be drawn:

1. Profitability and Leverage have no significant effect on Internet Financial Reporting with the direction of a positive regression coefficient. In other words, profitability and leverage can increase the use of Internet Financial Reporting. In contrast, Leverage does not have a significant effect on Internet Financial Reporting with a negative regression coefficient direction; in other words, liquidity can reduce the use of Internet Financial Reporting.

2. Company size has a significant influence on Internet Financial Reporting. Thus simultaneously, Company Size can increase the use of Internet Financial Reporting.

3. Partially the effect of Profitability, Liquidity, and Leverage on Internet Financial Reporting, which is moderated by Company Size is as follows:

a. The impact of profitability on Internet Financial Reporting can be corroborating even though it is not significant with Company Size as a moderating variable. Thus Company Size cannot moderate the relationship between Profitability and Internet Financial Reporting.

b. The Effect of Liquidity on Internet Financial Reporting can be corroborating and significant with Company Size as a moderating variable. Thus Company Size cannot moderate the relationship between Liquidity and Internet Financial Reporting.

c. The Effect of Leverage on Internet Financial Reporting can strengthen, although not significantly with Company Size as a moderating variable. Thus Company Size can moderate the relationship between Leverage and Internet Financial Reporting.

\section{Suggestion}

For further research, it is expected to add other variables. Besides, researchers can also enlarge the sample size by considering the research object and sample criteria as well as possible so that not too many samples are released in the sample selection process.

\section{REFERENCES}

1. Abdillah, M. R. (2017). Pengaruh Board Diversity Terhadap Internet Financial Repoting (IFR). Dinamika Ekonomi-Jurnal Ekonomi dan Bisnis, 10(1), 1-13.

2. Kurniawati, Y. (2018). Faktor-Faktor Yang Berpengaruh Pada Internet Financial Reporting (IFR) Di Perusahaan Manufaktur Yang Terdaftar Dalam Bursa Efek Surabaya (BES). Media Mahardhika, 16(2), 289-299.
3. Rizki, F., \& Ikhsan, A. E. (2018). Pengaruh Rasio Aktivitas, Resiko Sistemati, dan Tingkat Kepemilikan Saham terhadap Internet Financial Reporting (Studi pada Perusahaan Manufaktur yang Terdaftar di Bursa Efek Indonesia Periode 2011-2015). Jurnal Ilmiah Mahasiswa Ekonomi Akuntansi, 3(3), 443-458.

4. Abdillah, M. R. (2016). Pengaruh Pertumbuhan Perusahaan dan Risiko Perusahaan Terhadap Pengungkapan Internet Financial Reporting (IFR) Dinamika Ekonomi-Jurnal Ekonomi dan Bisnis, 9(2), 69-84.

5. Khikmawati, I. K., \& Agustina, L. (2015). Analisis rasio keuangan terhadap pelaporan keuangan melalui internet pada website perusahaan. Accounting Analysis Journal, 4(1).

6. Andriyani, R., \& Mudjiyanti, R. (2017). Pengaruh Tingkat Profitabilitas, Leverage, Jumlah Dewan Komisaris Independen dan Kepemilikan Institusional terhadap Pengungkapan Internet Financial Reporting (IFR) di Bursa Efek Indonesia. Kompartemen: Jurnal Ilmiah Akuntansi, 15(1).

7. Dinas, E., Riera, P., \& Roussias, N. (2015). Staying in the first league: Parliamentary representation and the electoral success of small parties. Political Science Research and Methods, 3(2), 187-204.

8. Dharmawan, C. I., Ulum, I., \& Wahyuni, E. D. (2017). Pengaruh Corporate Governance Index terhadap Ketepatan Waktu Corporate Internet Reporting (Studi Empiris pada Perusahaan Peserta Corporate Governance Perception Index). Kompartemen Jurnal Ilmiah Akuntansi, 15(2), 128-138.

9. Abdillah, M. R. (2015). Pengaruh Kepemilikan Saham Dan Kinerja Keuangan Terhadap Pengungkapan Internet Financial Reporting (IFR) (Studi Empiris Pada Perusahaan Manufaktur Yang Terdaftar Di Bursa Efek Indonesia Tahun 2013). Dinamika Ekonomi-Jurnal Ekonomi dan Bisnis, 8(2), 20-39.

10. Arfianda, R. (2017). Pengaruh Profitabilitas, Ukuran Perusahaan, Kepemilikan Saham Oleh Publik, dan Leverage Terdapat DI IFR ( Internet Financial Reporting) Dalam Perusahaan Manufaktur di BEI (Bursa Efek Indonesia). EQUITY, 3(1).

11. Brigham, E. dan Joel F. H. (2018). Dasar-dasar Manajemen Keuangan. Jakarta: Salemba Empat.

12. Malawat, M. G. (2017). Determinants and Comparison of Internet Financial Reporting in Developing Country and Developed Country of Southeast Asia (Case Study: Property and Real Estate Industry in Indonesia and Singapore). Jurnal Ilmiah Ekonomi Bisnis, 21(2).

13. Kasmir. (2015). Analisis Laporan Keuangan. Edisi 8. Jakarta: PT Raja Grafindo Persada.

14. Jaya, A. K., \& Verawaty, V. (2015). The accessibility determinants of internet financial reporting of Manufacture Company listed in 
Indonesia Stock Exchange. Asian Economic and Financial Review, 238-238.

15. Hanafi, M. M. dan Abdul H. (2016) .Analisa Laporan Keuangan. Yogyakarta: UPP STIM YKPN.

16. Sugiyono. (2014). Metode Penelitian Bisnis.

\section{Bandung: Alfabeta.}

17. Ghozali, I. (2016). Aplikasi Analisis Multivariate Dengan Program IBM SPSS 23 Update PLS Regresi. Edisi Delapan. Semarang: Badan PenerbitUniversitas Diponegoro. 